\title{
2009/12
}

On tax competition, public goods provision and jurisdictions' size

Patrice Pieretti and Skerdilajda Zanaj 
CORE

Voie du Roman Pays 34

B-1348 Louvain-la-Neuve, Belgium.

Tel (32 10) 474304

Fax (32 10) 474301

E-mail: corestat-library@uclouvain.be http://www.uclouvain.be/en-44508.html 


\title{
CORE DISCUSSION PAPER
}

$2009 / 12$

\section{On tax competition, public goods provision and jurisdictions' size}

\author{
Patrice PIERETTI ${ }^{1}$ and Skerdilajda ZANAJ ${ }^{2}$
}

March 2009

\begin{abstract}
In this paper, we analyse competition among jurisdictions to attract firms through low taxes on capital and/or high level of public goods, which enhance firms' productivity. We assume that the competing jurisdictions are different in (population) size and that the mobility of capital is costly. We find that for moderate mobility costs, small economies can attract foreign capital if they supply higher levels of public goods than larger jurisdictions, without being tax havens. If mobility costs are high, we recover the classical result that small jurisdictions are attractive to foreign capital if they engage in tax dumping. Finally, we show that there exists a subset of mobility costs for which the differentiation in public goods across jurisdictions is not able to relax tax competition.
\end{abstract}

Keywords: tax competition, public goods competition, spatial competition, foreign direct investments, country size.

JEL Classification: H25, H73, F13, F15, F22

\footnotetext{
${ }^{1}$ University of Luxembourg, CREA, Luxembourg.

${ }^{2}$ University of Luxembourg, CREA, Luxembourg; Université catholique de Louvain, CORE, B-1348 Louvainla-Neuve, Belgium.E-mail: skerdilajda.zanaj@uni.lu

We are grateful to Felix Bierbauer, Marie-Laure Breuillé, Ernesto Crivelli, Wolfgang Eggert, Jean Gabszewicz, Martin Hellwig, Jean Hindriks, John Weymark, and all the participants of PGPPE 2008 workshop at Max Planck Institute for very useful comments; to Luisito Bertinelli, Arnaud Bourgain, Pierre Picard, Gwenaël Piaser, Robert Vermeulen and Benteng Zou for stimulating discussions in CREA. The ususal disclaimer applies.

This paper presents research results of the Belgian Program on Interuniversity Poles of Attraction initiated by the Belgian State, Prime Minister's Office, Science Policy Programming. The scientific responsibility is assumed by the authors.
} 



\section{Introduction}

In this paper, we analyze competition among countries to attract entrepreneurs through low taxes on capital and/or high level of public goods, which enhance firms' productivity. We assume that the competing jurisdictions are different in (population) size and that the mobility of capital is costly. Our main interest is to investigate which type of country (small or large) is attractive to foreign investments and which instrument (taxes or public goods) is chosen by the successful jurisdiction.

Tax competition among countries to attract entrepreneurs or mobile shoppers has generated a large body of literature. Two topics have attracted particular attention. Firstly, the focus has been on the inefficiencies originated by capital mobility, which constitute the normative approach to tax competition (see for instance Zodrow and Mieszkowski (1986), Wilson (1995), Mintz and Tulkens (1986), Wildasin (1988ab), Bucovetsky (1991), Bucovetsky and Wilson (1991), Matsutmoto (1998), Bucovetsky, Marchand and Pestieau (1998)). A second topic of interest has been the study of the characteristics $^{1}$ that a country should possess to be the destination of investors and foreign consumers (Wilson, 1991, Kanbur and Keen (1993), Barros and Cabral (2000)), Bjorvatn and Eckel (2005), Haufler and Wooten (1999)). In this paper we adopt a similar positive approach rather than a normative one by focusing on the role of the size asymmetry of countries in attracting foreign investments.

A result which generally appears in the tax competition literature is that small jurisdictions benefit from low taxes. This comes from the fact that small countries face more elastic tax bases than larger countries, if tax rates were uniform (Hindriks and Myles (2006), Wilson (1991), Kanbur and Keen (1993)). Another argument that supports this feature is the homogeneity of population in small countries. Namely, wealthy individuals migrate to small jurisdictions in which they are able to democratically choose low taxes for themselves (Hansen and Kessler (2001)).

Importantly, if small countries were always to offer lower capital tax rates than the larger ones, then they would be importers of capital and exhibit a high capital-labor ratio. Marceau, Mongrain and Wilson (2007) use data from 1991 to 1999 , to show that this is not the case, and they claim that

\footnotetext{
${ }^{1}$ For example, the level of employment, population density, production technology, tariffs and subsidies.
} 
"the correlation between the size-population of a country and its tax rate is not clear. For example, some large countries like France and Germany have below average tax rates. (...) [T]he predictions of the asymmetric tax competition literature do not appear to be realized in the real world equilibrium." (Marceau, Mongrain and Wilson, 2007, pages 4-5).

Furthermore, recent data (Devereux et al, 2008) of effective corporate taxes show that some small countries like Belgium, Netherlands or Serbia set very low tax rates, even lower than countries of smaller size as Luxembourg. Some medium-sized countries like Austria set high rates as some large countries. Large countries are also divided in clusters of high taxes (Argentina, China, Russia, US, France) and low taxes (Bulgaria, Ukraine, Poland). Therefore, the evidence is that there is no monotonic increasing relationship between capital tax rates and the population size of jurisdictions.

The model we develop in our paper allows for a non-monotonic pattern of capital tax rates by assuming that countries of unequal size compete for foreign capital with taxes and public goods that improve firms' productivity. The existing literature has already analyzed the role of public goods differentiation in relaxing fiscal competition (Zissimos and Wooders, 2008 and Hindriks et al, 2008). Accordingly, tax rate differentials between competing jurisdictions may persist in equilibrium. In the same vein, the stratification of countries in different tax classes can be explained by the quality differentiation of public goods (Justman, van Ypersele and Thisse, 2001). BénassyQuéré et al (2007) also study joint competition on taxes and the provision of public goods that enhance consumers' utility and firms' productivity. They find in particular that both the amount of public R\&D expenditures as a share of GDP and the road infrastructure had a positive impact on FDIs flowing from the United States to European countries in 1994-2003.

In our model we consider two jurisdictions of uneven size, where size refers to population in a given jurisdiction ${ }^{2}$. There is a one to one relationship between a firm, an entrepreneur/worker and a unit of capital (productive

\footnotetext{
${ }^{2}$ Country size may be defined by its population, by its area, or by its national income (Streeten, 1993). In our paper, we focus on the population aspect rather than on the spatial size.We thus assume that spatial area will not be a physical limitation for newly established firms. We further focus on competition between jurisdictions that highly differ in size. Accordingly, we assume that when the population size is very small, it is likely that the endowment in human capital and entrepreneurs is very limited.
} 
resource), and entrepreneurs are heterogeneous according to their willingness to invest capital in a foreign location. Public goods that cover a wide range of infrastructures, services and regulations provided by the local and/or the central government are attractive to firms if they enhance their productivity $^{3}$. Accordingly, entrepreneurs decide where to locate capital according to differentials in offered public good levels and tax differentials. Competition between jurisdictions follows a two-stage game. First, governments decide on the level of public goods to supply, and then they set the tax rates to maximize their rents. This timing leads to a strategic effect of public good provision on tax competition intensity, because jurisdictions can anticipate in the first stage how harsh competition on taxes will be in the second stage.

The main findings are summarized as follows. A large jurisdiction can only be attractive to capital through the supply of higher levels of public goods than its small rival. Nevertheless, such a result only emerges if the mobility cost of capital is very low. Importantly, a small jurisdiction need not be a tax haven to be attractive to foreign investments. Indeed, for a certain range of mobility costs, it attracts foreign capital by supplying higher public goods than its larger rival without bidding lower taxes. For this equilibrium to occur we show that the cost level of mobility has to be intermediate and that no comparative advantage specific to small country size is necessary. However, adopting a tax haven behavior is a winning strategy for a small country if the mobility cost of capital is high enough. In this case, we recover the classical result that small countries are capital importers because of low taxes. Three general conclusions can be drawn: (i) The level of taxation on capital is not a sufficient measure for attractiveness. (ii) High taxes on capital may persist because of the high level of public goods supplied to attract capital. (iii) Other things being equal, the model finally shows that a certain degree of size asymmetry between jurisdictions is sufficient to define the direction of capital movements.

\footnotetext{
${ }^{3}$ In this context, we may consider transportation infrastructures, universities and public R\&D investment, but also property rights enforcement, capital market regulations, labor and enviromental regulations and the absence of red tape procedures. It follows that countries' ability to attract foreign investment may also be attractive for the quality of their institutions. In the Oxford Handbook of Entrepreneurship (2007), it is argued that the abundance of entrepreneurs in a country depends, among other factors, on the existence of regulations, property rights, accounting standards and disclosure requirements. Furthermore, in recent years there has been a surge of country and cross-country studies relating economic development to institutions, especially those affecting capital market development and functionality (La Porta et al. (1997) among others).
} 
Findings related to our paper can be found in Hindriks, Peralta and Weber (2008) and Zissimoss and Wooders (2008). Zissimos and Wooders (2008) address the inefficiency issues that may arise when jurisdictions compete both on taxes and public investments. They show that competition in public goods makes competition in taxes less fierce but has negative consequences for efficiency. We show that this impact on the intensity of tax competition may not always be true, since it depends on the size asymmetry of the competing jurisdictions and on the mobility cost of capital. Hindriks, Peralta and Weber (2008) also develop a model of tax and public goods competition with perfect capital mobility. Their aim is to investigate equalization schemes in federal states. They assume that jurisdictions are different in attractiveness because one possesses a superior production technology. This asymmetry can be altered by public investments. The authors find that a region can be attractive to capital even if its capital taxes are higher than its rival but its level of equilibrium investment is not efficient as in Zissimos and Wooders (2008). In both papers, inefficiency arises because jurisdictions make investment decisions at the first stage of the game and then compete in taxes. Hence, to make tax competition less fierce, jurisdictions invest inefficiently in public goods. We share with this paper the fact that fiscal choice is inefficient because of the strategic effect of public goods levels on tax competition intensity. However, the purpose of our paper is different.

Other contributions also deal with competition for capital between asymmetric jurisdictions. For example, Barros and Cabral (2000) consider a subsidy game between asymmetric countries to attract foreign direct investments in order to alleviate unemployment. At equilibrium, the winner is the country that gains the most in terms of employment for given transportation costs. Haufler and Wooten (1999) also consider competition for foreign investments by stressing the role of international trade costs and the "home market" effect. Since the authors consider asymmetric sized home markets, the large country will have an advantage in attracting foreign capital. In both papers, a small economy can only be attractive to foreign investments if it underbids the larger one in terms of taxes or if it overbids it in terms of subsidies. In our paper however, we show that the small country can win in interjurisdictional competition without being tax attractive.

The paper is organized as follows. The next section presents the model and defines the SPN equilibria of the two stage game. Section 3 presents the properties of such equilibria. Section 4 deals with attractiveness, while section 5 presents some efficiency issues. Section 6 concludes. 


\section{The model}

Consider two jurisdictions $h$ and $f$ of uneven size. The term jurisdiction refers indistinguishably to different regions of the same country or to different countries provided that these entities have the power to tax. As already mentioned, size refers to the magnitude of population which coincides with the number of capital-owners who are at the same time entrepreneurs and workers (one individual per firm). The types of capital-owners in $h$ (resp. $f$ ) are represented by the $[0,1]$-interval with density $s_{h}$ (resp. $s_{f}$ in country $f), s_{h}+s_{f}=1$. Assume without loss of generality that $h$ is the small jurisdiction, so $s_{h}<\frac{1}{2}$. The population of capital-owners ${ }^{4}$ is thus $s_{h}$ in the small country and $s_{f}$ in the large one. We further assume that the entrepreneurs are endowed with one unit of a capital good and that they differ in their willingness to invest abroad. So we assume that capital-owners are distributed over $[0,1]$ in an increasing order of their willingness to invest at home.

The technology is defined as follows. Each entrepreneur is able to combine one unit of capital good with her own labor to produce $q+a_{i},(i=h, f)$ units of a final good, where $q$ is the private component of (gross) productivity. This output good is sold in a competitive (world) market at a given price normalized to one. Assuming that both countries have equal access to a common market implies that the smallest jurisdiction does not suffer from a reduced home market. We further suppose that the unit production cost is constant and equal to zero without loss of generality.

The fraction $a_{i}(i=h, f)$ of the produced good depends on a public input supplied by jurisdiction $i=h, f$. This input may represent material and immaterial public infrastructures ${ }^{5}$. We further assume that one additional unit of the public service produces one additional unit of the private good. It follows that $a_{i}$ also represents the amount of public input supplied by jurisdiction $i=h, f$. Providing firms localized at $i=h, f$ with this public

\footnotetext{
${ }^{4}$ These exogenously given populations will not change since we consider entrepreneurs as commuters.

${ }^{5}$ The public input $a_{i}$ satisfies the local public good characteristic, which means that it is jointly used without rivalry by firms located in the same jurisdiction. It follows that the benefits and the costs of these good only accrue at the jurisdictional level. As in Zissimoss and Wooders (2008), we shall abstract from congestion costs . Taking account of congestion would complicate our framework without improving qualitatively the results. Moreover, if $a_{i}$ represents immaterial public goods as law and regulations (protecting intellectual property, specifying accurate dispute resolution rules,...), the absence of congestion is easily justified by the particular nature of these goods.
} 
input is costly. The corresponding cost function is given by $C\left(a_{i}\right)=a_{i}^{2}$ $(i=h, f)$.

Assume now that an entrepreneur of type $x, x \in[0,1]$, either invests one unit of physical capital in her country $i$, or she invests in the foreign jurisdiction $j$. If she invests in her home country, her profit is given by $\pi_{i}=q+a_{i}-t_{i}$, where $t_{i}$ denotes the tax in country $i$ levied on one unit of capital $^{6}$. If she invests abroad (country $j$ ), her profit becomes $q+a_{j}-t_{j}$ minus $k \cdot x$, which is the disutility of investing abroad given her type $x_{i}$. The coefficient $k$ represents a unit cost of moving capital abroad. This parameter can also be interpreted as a measure of the degree of international integration. We will see that the value of $k$ is critical in explaining how each country adjusts its attractiveness by being more tax and/or public-service attractive.

From now on we assume without loss of generality that investments flow from jurisdiction $i$ to $j$. For that purpose consider that the capital-owner of type $x_{i}$ is indifferent between investing abroad and staying at home if

$$
q+a_{i}-t_{i}=q+a_{j}-t_{j}-k x_{i}
$$

which yields

$$
x_{i}\left(a_{i}, a_{j}, t_{i}, t_{j}\right)=\frac{1}{k}\left[\left(a_{j}-a_{i}\right)+\left(t_{i}-t_{j}\right)\right] .
$$

In other words, country $j$ attracts capital from jurisdiction $i$ if the net gain of investing in $j$, i.e. $a_{j}-t_{j}$, is higher than the net gain obtained by staying in jurisdiction $i, a_{i}-t_{i}$, after taking into account the mobility cost. Attractiveness of jurisdiction $j$ can be decomposed in two dimensions: tax attractiveness $\Delta_{t}=t_{i}-t_{j}$ and public goods attractiveness, $\Delta_{a}=a_{j}-a_{i}$.

Definition 1 A jurisdiction is tax attractive if it levies the lowest level of taxes on capital compared to other jurisdictions.

Definition 2 A jurisdiction is public goods attractive if it supplies the highest level of public good services compared to other jurisdictions.

From equation (1) it also follows that the firms belonging to the types in the interval $\left[0, x_{i}\right]$ will move abroad. In other words, $s_{i} x_{i}$ entrepreneurs will move $s_{i} x_{i}$ units of capital from country $i$ to country $j$. It follows that there

\footnotetext{
${ }^{6}$ For the sake of simplicity, we shall assume that $q$ is such that the profit of each firm is positive for all equilibrium level of public goods and taxes.
} 
are four scenarios for representing the tax bases of the capital exporting and capital importing countries

\begin{tabular}{|c|c|c|}
\hline Country & Capital exporting $(i)$ & Capital importing $(j)$ \\
\hline Small $(h)$ & $s_{h}-s_{h} x_{h}$ & $s_{h}+\left(1-s_{h}\right) x_{f}$ \\
\hline Large $(f)$ & $\left(1-s_{h}\right)-\left(1-s_{h}\right) x_{f}$ & $\left(1-s_{h}\right)+s_{h} x_{h}$ \\
\hline
\end{tabular}

Jurisdictions are assumed to maximize their tax revenue net of public investment cost. According to the above table, the payoff function of the capital exporting jurisdiction $i(i=h, f)$ is

$$
B_{i}\left(a_{i}, a_{j}, t_{i}, t_{j}\right)=s_{i}\left(1-x_{i}\right) t_{i}-a_{i}^{2} .
$$

For the capital importing jurisdiction $j(j=h, f)$ we have

$$
B_{j}\left(a_{i}, a_{j}, t_{i}, t_{j}\right)=\left[\left(1-s_{i}\right)+s_{i} x_{i}\right] t_{j}-a_{j}^{2}
$$

After substituting (1) in (2) and (3) we obtain

$$
\begin{aligned}
& B_{i}\left(a_{i}, a_{j}, t_{i}, t_{j}\right)=-\frac{1}{k} s_{i} t_{i}^{2}+\left[\frac{1}{k} s_{i}\left(a_{i}-a_{j}+t_{j}\right)+s_{i}\right] t_{i}-a_{i}^{2}, \\
& B_{j}\left(a_{i}, a_{j}, t_{i}, t_{j}\right)=-\frac{1}{k} s_{i} t_{j}^{2}+\left[\frac{1}{k} s_{i}\left(a_{j}-a_{i}+t_{i}\right)+1-s_{i}\right] t_{j}-a_{j}^{2} .
\end{aligned}
$$

The two jurisdictions play a two stage game. First, they decide on the quantity of public goods to provide. Then they select the level of taxes. The choice of sequentiality follows from the rule that the most irreversible decision has to be taken first. The game is solved through backward induction. Given the couple $\left(k, s_{i}\right), i=h, f$, the SPNE of the game is defined as $\left(a_{i}\left(k, s_{i}\right), a_{j}\left(k, s_{i}\right), t_{i}\left(k, s_{i}\right), t_{j}\left(k, s_{i}\right)\right)$ for $i, j=h, f, i \neq j$.

\subsection{The tax game}

Each jurisdiction maximizes its budget with respect to its own tax rate, assuming that its rival's tax is given and the level of public services is fixed in the first stage

$$
\begin{gathered}
\underset{t_{i}}{\operatorname{Max}} B_{i}\left(t_{i}, t_{j}\right) \\
\operatorname{Max}_{t_{j}} B_{j}\left(t_{i}, t_{j}\right)
\end{gathered}
$$


The objective functions are strictly concave in $t_{i}$ and $t_{j}\left(\frac{\partial^{2} B_{i(j)}}{\partial t_{i(j)}^{2}}=-\frac{2 s_{i(j)}}{k}<0\right)$ and the first order conditions yield the following the best reply functions

$$
\begin{aligned}
t_{i}\left(t_{j}\right) & =\frac{t_{j}}{2}+\frac{\left(a_{i}-a_{j}\right)}{2}+\frac{k}{2} \\
t_{j}\left(t_{i}\right) & =\frac{t_{i}}{2}+\frac{\left(a_{j}-a_{i}\right)}{2}+\frac{1-s_{i}}{s_{i}} \frac{k}{2} .
\end{aligned}
$$

Clearly, taxes are strategic complements and best reply functions have slopes smaller than one. Accordingly, there exists a unique equilibrium in tax rates given by

$$
\begin{aligned}
& \widetilde{t}_{i}\left(a_{i}, a_{j}\right)=\frac{\left(a_{i}-a_{j}\right)}{3}+\frac{1}{3} \frac{1+s_{i}}{s_{i}} k, \\
& \widetilde{t}_{j}\left(a_{i}, a_{j}\right)=\frac{\left(a_{j}-a_{i}\right)}{3}+\frac{1}{3} \frac{2-s_{i}}{s_{i}} k
\end{aligned}
$$

Notice the negative strategic effect of public good provision of country $j$ on the tax rate of country $i$, and vice versa. This means that each jurisdiction has an incentive to dampen its own investment on public goods to restrain the incentive of the rival jurisdiction to engage in a tax cutting behavior. This is similar to Hindriks et al (2008) and Zissimos and Wooders (2008) who show that public goods will be supplied inefficiently.

Substituting the tax values in (5a) and (5b), we finally have

$$
\begin{aligned}
B_{i}\left(a_{i}, a_{j}\right) & =-\frac{9 k-s_{i}}{9 k} a_{i}^{2}+\frac{2}{9 k}\left[k\left(1+s_{i}\right)-s_{i} a_{j}\right] a_{i}+\frac{1}{9 k s}\left[k\left(1+s_{i}\right)-s_{i} a_{j}\right]^{2}, \\
B_{j}\left(a_{i}, a_{j}\right) & =-\frac{9 k-s_{i}}{9 k} a_{j}^{2}+\frac{2}{9 k}\left[k\left(2-s_{i}\right)-s_{i} a_{i}\right] a_{j}+\frac{1}{9 k s_{i}}\left[k\left(2+s_{i}\right)-s_{i} a_{i}\right]^{2} .
\end{aligned}
$$

\subsection{Competition in public goods}

At the first stage, each jurisdiction maximizes its budget with respect to its own public input

$$
\begin{gathered}
\underset{a_{i}}{\operatorname{Max}} B_{i}\left(a_{i}, a_{j}\right) \\
\underset{a_{j}}{\operatorname{Max}} B_{i}\left(a_{i}, a_{j}\right)
\end{gathered}
$$


From the first order conditions, the resulting best replies are

$$
\begin{aligned}
& a_{i}\left(a_{j}\right)=-\frac{s_{i}}{9 k-s_{i}} a_{j}+\frac{k\left(1+s_{i}\right)}{9 k-s_{i}}, \\
& a_{j}\left(a_{i}\right)=-\frac{s_{i}}{9 k-s_{i}} a_{i}+\frac{k\left(2-s_{i}\right)}{9 k-s_{i}} .
\end{aligned}
$$

In the following, we assume that $9 k-s_{i}>0\left(k>\frac{s_{i}}{9}\right)$. Accordingly, the objective functions are strictly concave in $t_{h}$ and $t_{f}\left(\frac{\partial^{2} B_{i(j)}}{\partial a_{i(j)}^{2}}=-\frac{9 k-s_{i}}{9 k}<0\right)$ and public goods are strategic substitutes. The equilibrium in public services is then

$$
\begin{aligned}
a_{i}^{*} & =\frac{1}{3} \frac{3 k\left(1+s_{i}\right)-s_{i}}{9 k-2 s_{i}} \\
a_{j}^{*} & =\frac{1}{3} \frac{3 k\left(2-s_{i}\right)-s_{i}}{9 k-2 s_{i}}
\end{aligned}
$$

Introducing the equilibrium public services into equations (5a) and (5b) yields equilibrium tax rates

$$
\begin{aligned}
t_{i}^{*} & =\frac{3 k}{s_{i}} a_{i}^{*}, \\
t_{j}^{*} & =\frac{3 k}{s_{i}} a_{j}^{*} .
\end{aligned}
$$

Remembering the concavity condition, the above equilibrium values are positive if $\frac{s_{h}}{9}<k<\frac{s_{h}}{3\left(2-s_{h}\right)}$ or $k>\frac{s_{h}}{3\left(1+s_{h}\right)}$ for $i=h$, and $\frac{1-s_{h}}{9}<k<\frac{1-s_{h}}{3\left(2-s_{h}\right)}$ or $k>\frac{1-s_{h}}{3\left(1+s_{h}\right)}$ if $i=f$. For these parameter values, the equilibrium of the game is unique because the best replies in each stage of the game satisfy uniqueness conditions.

At equilibrium we see that $a_{j}^{*}-a_{i}^{*}=\frac{k}{9 k-2 s_{i}}\left(1-2 s_{i}\right)$. Since $t_{i}^{*}\left(t_{j}^{*}\right)$ and $a_{i}^{*}\left(a_{j}^{*}\right)$ have the same sign, it can easily be checked that $a_{j}^{*}-a_{i}^{*}>0$ and $t_{j}^{*}-t_{i}^{*}>0$ if $k>\frac{2}{9} s_{i}$. More precisely, for $i=h$, we have $a_{f}^{*}-a_{h}^{*}=$ $\frac{k}{9 k-2 s_{h}}\left(1-2 s_{h}\right)>0$ if $k>\frac{2}{9} s_{h}$ and for $i=f$, we get $a_{h}^{*}-a_{f}^{*}=\frac{k}{9 k-2 s_{f}}\left(1-2 s_{f}\right)<$ 0 if $k>\frac{2}{9} s_{f}$. From both cases it follows that the small country adopts a tax haven behavior $\left(t_{f}^{*}>t_{h}^{*}\right)$ and supplies lesser public goods than its larger rival $\left(a_{h}^{*}<a_{f}^{*}\right)$ if $k>\bar{k}=\frac{2}{9} s_{i}$. By contrast, if $k<\bar{k}$ the small country switches to a quite opposite behavior. It follows that the classical result according to which small countries are tax havens hinges on the condition that capital 
mobility has to exceed a trigger value $\bar{k}$, which decreases with the degree of size asymmetry between the competing jurisdictions.

Proposition 3 The smaller jurisdiction behaves as a tax haven if the cost of capital mobility exceeds the trigger value $\bar{k}=\frac{2}{9} s_{i}$. However, if capital mobility is high enough $(k<\bar{k})$, the smaller jurisdiction offers more capital goods than its rival and ceases to be a tax $h(e) a v e n^{7}$.

Nevertheless, the above proposition says nothing about countries' attractiveness to foreign capital. For that purpose we need to analyze the direction of capital movements. We thus substitute the equilibrium values of tax rates and public goods in (1) to obtain the flow of capital moving from $i$ to $j$

$$
x_{i}^{*}=\frac{\left(1-2 s_{i}\right)\left(s_{i}-3 k\right)}{s_{i}\left(9 k-2 s_{i}\right)}, i=h, f
$$

It follows that $0<x_{h}^{*}<1$ if $\frac{s_{h}}{3\left(1+s_{h}\right)}<k<\frac{s_{h}}{3}$, while $0<x_{f}^{*}<1$ if $k>\frac{1-s_{h}}{3}$ or $k<\frac{1-s_{h}}{3\left(2-s_{h}\right)}$. We can then state the following

Lemma 4 The capital importer is the large country $f\left(x_{h}^{*}>0\right)$ if

$$
k \in\left(\frac{s_{h}}{3\left(1+s_{h}\right)}, \frac{s_{h}}{3}\right),
$$

The capital importer is a small country $\left(x_{f}^{*}>0\right)$ if

$$
k \in\left\{\left(\frac{1-s_{h}}{9}, \frac{1-s_{h}}{3\left(2-s_{h}\right)}\right) \cup\left(\frac{1-s_{h}}{3}, \frac{1}{3}\right)\right\}
$$

Note also that sets of $k$ defined in Lemma 4 may overlap. If the subset $\Omega=$ $\left(\frac{s_{h}}{3\left(1+s_{h}\right)}, \frac{s_{h}}{3}\right) \cap\left(\frac{1-s_{h}}{9}, \frac{1-s_{h}}{3\left(2-s_{h}\right)}\right)$ is not empty, we cannot univocally determine which country, the large or the small, is the destination for FDIs ${ }^{8}$.

\footnotetext{
${ }^{7}$ We borrow this termonology from Hansen and Kessler (2001).

${ }^{8}$ The overlapping of sets does not lead to two-way flows. In fact, the types of entrepreneurs in one jurisdiction differ by their willingness to move abroad, but the set of types is the same across jurisdictions. Therefore, given the equilibrium quantities of public goods and taxes for each jurisdiction, there is only a one-way migration flow. In other words, if $x_{i} s_{i}$ entrepreneurs decide to invest in $j$, it is not possible, that for the same parameters $\left(s_{i}, k\right)$, there are entrepreneurs quitting $j$.
} 
Indeed for each value $k$ belonging to this intersection, we obtain two competing equilibria. One for $\left(s_{h}, k\right)$ and one for $\left(1-s_{h}, k\right)^{9}$. In the first case, the big country is the destination for FDIs, while in the second case foreign investments flow to the small country. The source of this indeterminacy resides in the size asymmetry of the competing jurisdictions. Indeed it is easy to check that $\Omega=\varnothing$ if $0 \leq s_{h}<\frac{1}{4}$. It follows that, other things being equal, size difference between jurisdictions may matter in defining the direction of FDIs. From now on, we assume that $s_{h}$ will be small enough in order to eliminate this indeterminacy. Accordingly, the intervals given in Lemma 4 are ordered in the following way. In the interval $\left(\frac{s_{h}}{3(1+s)}, \frac{s_{h}}{3}\right)$, mobility costs will be said low, in the interval $\left(\frac{1-s_{h}}{9}, \frac{1-s_{h}}{3\left(2-s_{h}\right)}\right)$ we say they are moderate and high in $\left(\frac{1-s_{h}}{3}, \frac{1}{3}\right)^{10}$. It thus follows that very small jurisdictions may not import capital if capital mobility is high enough unless these jurisdictions enjoy a specific comparative advantage ${ }^{11}$.

At this stage, the nature of attractiveness for capital (because of tax or public goods attractiveness) in each set of equilibria is not precised. This issue will be addressed in the following section.

Finally, for sake of clarity, we present in Fig 1 the sets of parameters $\left(k, s_{i}\right)$ which generate different pattern of capital movements. The yellow colored areas show the parameter domains where there are international capital movements $\left(x_{h}>0\right.$ or/and $\left.x_{f}>0\right)$. For the parameter values corresponding to the white areas there are no capital flows between jurisdictions $\left(x_{h}=0\right.$ and $\left.x_{f}=0\right)$. Finally, in the grey areas parameter values are not admissible since positiveness, boundary and concavity conditions are not met in these subsets.

\footnotetext{
${ }^{9}$ More exactly, we have a unique equilibrium for $\left(s_{h}, k\right)$ and another unique equilibrium corresponding to $\left(1-s_{h}, k\right)$.

${ }^{10}$ For sake of completeness, notice that in the intervals we excluded in Lemma 4, either there is no capital flow, or the whole capital emigrates $\left(x_{i}=1\right)$. Indeed, consider the case when FDIs may stem from the small country $\left(s_{i}=s_{h}\right)$. For the values of $k$ contained in $\left(\frac{s_{h}}{9}, \frac{2 s_{h}}{9}\right)$ and $\left(\frac{s_{h}}{3}, \frac{1}{3}\right)$ there are no foreign investments at all $\left(x_{h}^{*}=0\right)$. If $k \in$ $\left(\frac{2 s_{h}}{9}, \frac{s_{h}}{3\left(1+s_{h}\right)}\right]$, we have the extreme case in which all the entrepreneurs move from $h$ to $f$. In this interval, the small jurisdiction produces no public goods $\left(a_{h} \leq 0\right)$ and levies no taxes $\left(t_{h} \leq 0\right)$. Similar arguments apply, mutadis mutandis, when $s_{i}=s_{f}$.

${ }^{11}$ Small economies are likely to have greater cohesion and thus social flexibility and openness to change. These attributes create conditions of political and social stability and absence of bureaucratic red tape, which may give very small economies a comparative advantage in attracting foreign firms (Streeten, 1993).
} 


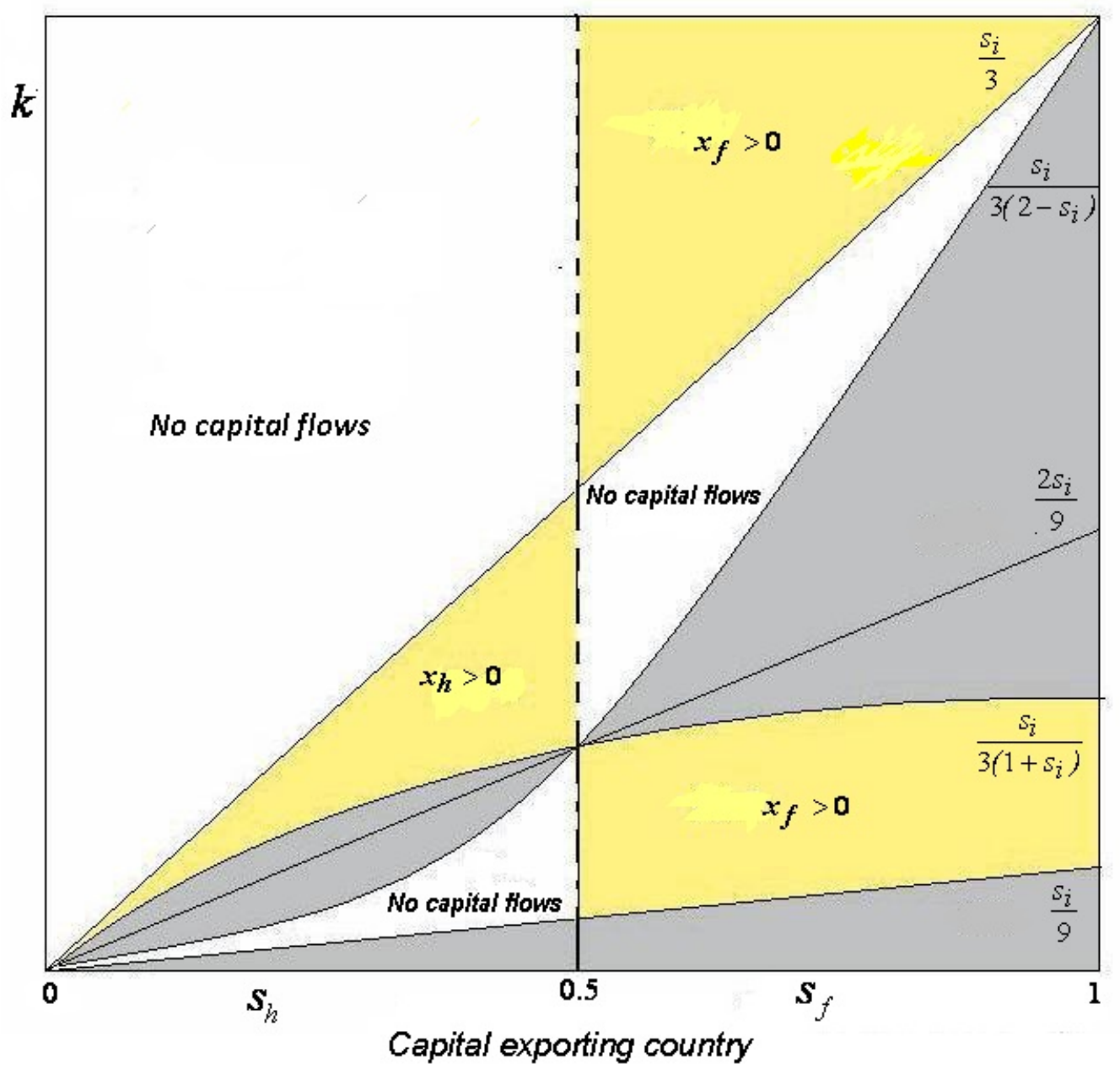

Figure 1: Equilibrium sets

\section{Tax vs. public goods attractiveness}

In this section, we show that there exist equilibria where small and/or large jurisdictions may be attractive to foreign capital not necessarily due to tax motives. Proposition 3 shows that large jurisdictions can be tax $\mathrm{h}(\mathrm{e})$ avens and small ones can be tax hells. This section is intended to provide a better understanding of these possible outcomes and, more generally, to precise the 
type of equilibrium strategies the attractive jurisdiction chooses.

Recall that Kanbur and Keen (1993) argue that a small jurisdiction always fixes lower taxes than a larger one because it faces a greater potential of cross border shoppers and is thus confronted with a more (tax) elastic demand (if tax rates were identical). It also follows that the small country will be the capital importer since, by assumption, tax advantages are the only reason for investing abroad. In our model, jurisdictions face the following capital supplies, which are also the tax bases (see table in section 2):

$$
\begin{aligned}
& S_{i}\left(t_{i}, t_{j}, a_{i}, a_{j}\right)=s_{i}\left(1-\frac{1}{k}\left(\left(a_{j}-a_{i}\right)+\left(t_{i}-t_{j}\right)\right)\right) \\
& S_{j}\left(t_{i}, t_{j}, a_{i}, a_{j}\right)=1-s_{i}\left(1-\frac{1}{k}\left(\left(a_{j}-a_{i}\right)+\left(t_{i}-t_{j}\right)\right)\right)
\end{aligned}
$$

Accordingly we obtain the following tax elasticities:

$$
\begin{aligned}
\epsilon_{i} & =\frac{\partial S_{i}}{\partial t_{i}} \frac{t_{i}}{S_{i}}=-\frac{1}{k} \frac{t_{i}}{1-\frac{1}{k}\left(\left(a_{j}-a_{i}\right)+\left(t_{i}-t_{j}\right)\right)} \\
\epsilon_{j} & =\frac{\partial S_{j}}{\partial t_{j}} \frac{t_{j}}{S_{j}}=-\frac{1}{k} s_{i} \frac{t_{j}}{1-s_{i}\left(1-\frac{1}{k}\left(\left(a_{j}-a_{i}\right)+\left(t_{i}-t_{j}\right)\right)\right)}
\end{aligned}
$$

Assume that taxes are equalized and public goods levels are not different $\left(t_{i}=t_{j}=t ; a_{j}=a_{i}\right)$. The small country, say $i$, will face the most elastic capital supply since $\left|\epsilon_{h}\right|=\frac{t}{k}>\left|\epsilon_{f}\right|=\frac{t}{k} \frac{s_{h}}{1-s_{h}}{ }^{12}$. We thus recover the case of Kanbur and Keen (1993). We do not get such a univocal result if we now assume that jurisdictions offer different public good levels $\left(a_{j} \neq a_{i}\right)$. Assume that the small jurisdiction has a competitive advantage in terms of public inputs $\left(a_{h}-a_{f}>0\right)$ and $i=f$ and $j=h$. If this advantage is sufficiently high $\left(a_{h}-a_{f}>\tilde{\Delta}_{a}=\frac{1-2 s_{h}}{2\left(1-s_{h}\right)} k\right)$, we get $\left|\epsilon_{f}\right|=\frac{t}{k} \frac{1}{1-\frac{1}{k}\left(a_{h}-a_{f}\right)}>$ $\left|\epsilon_{h}\right|=\frac{t}{k} \frac{s_{f}}{1-s_{f}\left(1-\frac{1}{k}\left(a_{h}-a_{f}\right)\right)}$ for $t_{h}=t_{f}=t$. This creates an incentive for the large jurisdiction to cut its taxes. Hence, small jurisdictions can be tax hells, or large jurisdictions can be tax $\mathrm{h}(\mathrm{e})$ avens, because tax elasticity of capital supply can be altered by the difference $a_{i}-a_{j}$.

Let us now analyze the relative importance of taxes and public goods in explaining why a jurisdiction may be attractive to foreign capital. We first

\footnotetext{
${ }^{12}$ We get the same result if $i=f$ while $j=h$ since $\left|\epsilon_{h}\right|=\frac{t}{k} \frac{s_{f}}{1-s_{f}}>\left|\epsilon_{f}\right|=\frac{t}{k}$.
} 
consider when the large jurisdiction is successful in winning the attractiveness game. The following proposition results.

Proposition 5 If a large jurisdiction imports foreign capital, it is only because it is attractive in terms of public goods.

Proof. Consider the first part of the Lemma (4). Since foreign investment stems from the small jurisdiction $h$, it is required that $k \in\left(\frac{s_{h}}{3\left(1+s_{h}\right)}, \frac{s_{h}}{3}\right)$. Since $k>\frac{s_{h}}{3\left(1+s_{h}\right)}>\frac{2 s_{h}}{9}$, it follows from equations (8), (9), (10) and (11) that $t_{h}^{*}<t_{f}^{*}$ and $a_{f}^{*}>a_{h}^{*}$.

Thus, for high mobility, i.e. $k \in\left(\frac{s_{h}}{3\left(1+s_{h}\right)}, \frac{s_{h}}{3}\right)$, the small country's best tax strategy is to undercut the large country at equilibrium. This result is reminiscent of Keen and Kanbur (1993), but with the proviso, that the small country is not successful in attracting foreign investments even if it engages in tax haven behavior. The reason is that the large country's relative attractiveness in terms of public inputs outweighs the small country's tax attractiveness. The intuition underlying this aggressive reaction in terms of public goods provision may be explained as follows. At equilibrium, the jurisdiction $f$ considers that capital mobility is high enough to pose a threat for potential tax base losses. In fact, when mobility is high, the small jurisdiction faces an elastic capital supply, which induces a tax cutting behavior. Consequently, the large country has an incentive to react strongly by supplying a much higher level of public goods than its rival.

This behavior can explain the persistence of high taxes in big jurisdictions. Indeed, high level of taxation may be essential for those countries to be able to supply high level of public services to attract foreign capital. This result is the same as in Zissimos and Wooders (2008) but the mechanism is different.

As far as small jurisdictions are concerned, we may state the following results

Proposition 6 A small jurisdiction is attractive to foreign investors:

(i) in terms of public goods, notwithstanding its high taxes if the level of mobility cost is moderate; and

(ii) in terms of taxes, notwithstanding its low public goods supply if the level of mobility cost is high. 
Proof. Consider the second point of Lemma (4). Since foreign investment stems from the big jurisdiction $f, s_{i}=s_{f}=1-s_{h}$,

(i) for moderate $k$, we get $t_{h}^{*}>t_{f}^{*}$ and $a_{h}^{*}>a_{f}^{*}$ since $k<\frac{s_{h}}{3\left(1+s_{h}\right)}<\frac{2 s_{h}}{9}$

(ii) for high $k$, we get $t_{h}^{*}<t_{f}^{*}$ and $a_{h}^{*}<a_{f}^{*}$ since $k>\frac{s_{h}}{3\left(1+s_{h}\right)}>\frac{2 s_{h}}{9}$.

When the mobility cost is intermediate, namely $k \in\left(\frac{1-s_{h}}{9}, \frac{1-s_{h}}{3\left(2-s_{h}\right)}\right)$, the big jurisdiction undercuts its small rival in taxes but is not successful in attracting foreign capital. For this range of values, the small country faces an elasticity of capital which is not as large as in the high mobility range. Its incentive for tax dumping is therefore tempered. On the other hand, in face of intermediate mobility costs, the large country has weak incentives to supply high levels of public goods. The balance of these two forces is that the small jurisdiction counteracts its rival by supplying a much higher level of public goods. This appears by looking at the elasticity (see (15)) faced by the small jurisdiction as a capital importer $\left(\epsilon_{h}=\epsilon_{j}\right)$. Indeed, if the differential in public goods is high enough $\left(a_{h}-a_{f}>0\right)$, the small jurisdiction alters its perceived elasticity to such an extent that it does not need to undercut its rival's tax.

When the mobility cost is high $\left(k \in\left(\frac{1-s_{h}}{3}, \frac{1}{3}\right)\right)$, the tax base is captive enough to lead the large jurisdiction to select high taxes, inducing the small one to be a tax $\mathrm{h}(\mathrm{e})$ aven. In other words, the small jurisdiction opts for tax-cutting because its rival sets high taxes.

To summarize our results, (i) a tax hell can be attractive to foreign firms and (ii) small jurisdictions can be tax hells as well as tax h(e)avens, according to the degree of international integration.

Finally, we ask if higher international differentiation in public goods will reduce the intensity in (capital) tax competition. Derivating $\Delta_{a}^{*}$ and $\Delta_{t}^{*}$ with respect to $k$ shows that there is no monotonic relationship ${ }^{13}$ between $\Delta_{a}^{*}$ and $\Delta_{t}^{*}$. When $k \in\left(\frac{1-s_{h}}{3}, \frac{1}{3}\right)$, we obtain $\frac{\partial \Delta_{a}^{*}}{\partial k}<0$, while $\frac{\partial \Delta_{t}^{*}}{\partial k}$ can be positive or negative. Thus, in the considered interval for $k$, higher mobility leads jurisdictions to differentiate in public goods, but tax differentials may not move in the same direction since a higher $k$ can cause a reduction in $\Delta_{t}^{*}$. Indeed, when the mobility cost falls within the range $\left(\frac{1-s_{h}}{3}, \frac{1}{3}\right)$, the large jurisdiction may need to increase relatively to its small rival its level of public goods and decrease its taxes to contain the outflow of entrepreneurs. This strategic move leads to a higher $\Delta_{a}^{*}$ and a smaller $\Delta_{t}^{*}$. For all other admissible

\footnotetext{
${ }^{13}$ The derivates are given in Appendix 1.
} 
sets of $k$, higher capital mobility (lower $k$ ) entices jurisdictions to differentiate (higher $\Delta_{a}^{*}$ ) and tax competition is less intense (higher $\Delta_{t}^{*}$ ).

Proposition 7 There exists a range of $k$ values such that an increase in capital mobility increases tax competition even if jurisdictions differentiate in public goods.

\section{Conclusions}

This paper investigates the relationship between country size (population) and attractiveness to international capital. Attractiveness is built through public goods or services that improve firms' productivity and low taxes on capital. Entrepreneurs face different costs of mobility according to their willingness to locate their capital in a foreign country. We show that when the mobility cost is low or moderate, a jurisdiction can only be attractive through the supply of higher levels of public goods and not through lower taxes. However, adopting a tax haven behavior may only be a winning strategy if the mobility cost is high enough. Another important conclusion is that small jurisdictions may attract international capital by supplying a high level of public goods and without being tax havens. For this equilibrium to occur we show that the cost level of mobility has to be intermediate and that no comparative advantage specific to small country size is necessary.

This paper can be extended along different lines. One extension would be to develop a dynamic model of repeated games to capture a possible learning effect of governments concerning the self-selection of entrepreneurs. It would also be interesting to introduce labor or different types of capital to control for different degrees of mobility in order to check the effects of preferential taxation, namely, the switch of the burden of taxes on less mobile factors. 


\section{Appendix}

Here we study the sign of the derivatives $\Delta_{a}^{*}=k \frac{2 s_{i}-1}{9 k-2 s_{i}}$ and $\Delta_{t}^{*}=k \frac{3 k\left(2 s_{i}-1\right)}{s_{i}\left(9 k-2 s_{i}\right)}$ wrt to $k$.

1. In the intervals $k \in\left(\frac{s_{i}}{3\left(1+s_{i}\right)}, \frac{s_{i}}{3}\right)$ and $k \in\left(\frac{s_{i}}{9}, \frac{s_{i}}{3\left(1+s_{i}\right)}\right)$, derivating wrt to $k$ gives $\frac{\partial \Delta_{a}^{*}}{\partial k}=2 \frac{\left(2 s_{i}-1\right) s_{i}}{\left(9 k-2 s_{i}\right)^{2}}<0$ and $\frac{\partial \Delta_{t}^{*}}{\partial k}=\frac{3\left(9 k-4 s_{i}\right)\left(1-2 s_{i}\right) k}{\left(2 s_{i}-9 k\right)^{2} s_{h}}$. The sign of the last derivative depends on the sign of $9 k-4 s_{i}$. When $9 k-4 s_{i}>0$, we get $\frac{\partial \Delta_{t}^{*}}{\partial k}>$ 0 . This implies $k>\frac{4}{9} s_{i}$, which is inconsistent with $k \in\left(\frac{s_{i}}{3\left(1+s_{i}\right)}, \frac{s_{i}}{3}\right)$ and $k \in\left(\frac{s_{i}}{9}, \frac{s_{i}}{3\left(1+s_{i}\right)}\right)$. So, $\frac{\partial \Delta_{t}^{*}}{\partial k}<0$. Hence, when the big or the small jurisdiction are attractive because of the high level of public goods they provide, there is comovement in tax and public goods attractiveness when capital mobility increases.

2. Consider now $k \in\left(\frac{s_{i}}{3}, \infty\right)$. If $\Delta_{a}^{*}>0$ and $\Delta_{t}^{*}>0$, remember that entrepreneurs emigrate from jurisdiction $f$ to avoid high taxes. Derivating the tax and public goods differentials gives $\frac{\partial \Delta_{a}^{*}}{\partial k}=\frac{2 s_{f}\left(1-2 s_{f}\right)}{\left(9 k-2 s_{f}\right)^{2}}<0$ and $\frac{\partial \Delta_{t}^{*}}{\partial k}=$ $3 \frac{k}{s_{f}} \frac{2 s_{f}-1}{\left(9 k-2 s_{f}\right)^{2}}\left(9 k-4 s_{f}\right)$. It may be shown that for $k \in\left(\frac{1-s_{h}}{3} ; \frac{4}{9}\left(1-s_{h}\right)\right), \frac{\partial \Delta_{a}^{*}}{\partial k}$ and $\frac{\partial \Delta_{t}^{*}}{\partial k}$ are identically signed. However, for $k \in\left(\frac{4}{9}\left(1-s_{h}\right), \infty\right)$, we have $\frac{\partial \Delta_{a}^{*}}{\partial k}<0$ and $\frac{\partial \Delta_{t}^{*}}{\partial k}>0$.In this case, there is no more comovement in tax and public goods attractiveness when capital mobility increases.

\section{References}

[1] Barros P. and Cabral L., 2000, Competing for foreign direct investment, Review of International Economics, 8(2), 360-371.

[2] Benassy-Quéré A., Gobalraja N. and Trannoy A., Tax and public input competition, Economic Policy, 22 (50), pp. 385-430, 2007.

[3] Bucovetsky S. , 1991, Asymmetric tax competition, Journal of Urban Economics, Elsevier, vol. 30(2), 167-181.

[4] Bucovetsky S. and Wilson J.D., 1991., Tax competition with two tax instruments, Regional Science and Urban Economics, Elsevier, vol. 21(3), pages 333-350. 
[5] Devereux M.P. , Lockwood B. and Redoano M., 2008, "Do countries compete over corporate tax rates?" Journal of Public Economics 2008, 92.5-6, 1210-1235.

[6] Hansen Nico A. and Kessler Anke S., 2001. "The Political Geography of Tax H(e)avens and Tax Hells," American Economic Review, vol. 91(4), pages 1103-1115.

[7] Haufler A. and Wooton I., 1999, Country size and tax competition for foreign direct investment, Journal of Public Economics, 71, 121-139.

[8] Hindriks J. and Myles G. D., 2006, Intermediate Public Economics, The MIT Press. (Cap. 18).

[9] Hindriks J, Peralta S., Weber Sh., 2008, Competing in taxes and investment under fiscal equalization, Journal of Public Economics, Volume 92, Issue 12, Pages 2392-2402.

[10] Justman M., Thisse J.F. and van Ypersele T., 2001, Taking the bite out of fiscal competition, Journal of Urban Economics, 52 (2), 294-315.

[11] Kanbur, R. and Keen, M., 1993. Jeux sans frontières: Tax competition and tax coordination when countries differ in size, American Economic Review 83, 877-892.

[12] Kjetil b. and Eckel C., 2005, Policy competition for foreign direct investment between asymmetric countries, European Economic Review, 50(7), 1891-1907.

[13] La Porta R., López-de-Silanes F., Shleifer A. and Vishny R.., 1997b, Trust in Large Organizations, American Economic Review Papers and Proceedings, Vol. 97, Iss. 2, 333-339.

[14] Marceau N., Mongrain S., and Wilson J.D., 2007, Why do most countries set hig taxes rates on capital, Discussion paper of Centre Interuniversitaire sur le Risque, les Politiques Economiques et l'Emploi, 07-11

[15] Matsumoto M., 1998, A note on tax competition and public input provision, Regional Science and Urban Economics, 28, 465-473. 
[16] Mintz, Jack and Tulkens, Henry, 1986. , Commodity tax competition between member states of a federation: equilibrium and efficiency, Journal of Public Economics, Elsevier, vol. 29(2), pages 133-172.

[17] Streeten, P. 1993. "The Special Problems of Small Countries." World Development, 21(2), 197-202.

[18] Zissimos B. and Wooders M., 2008, Public good differentiation and the intensity of tax competition, Journal of Public Economics, 92 (5-6), 11051121.

[19] Zodrow G. and Mieszkowski P., 1986, Pigou, Tiebout, property taxation, and the underprovision of local public goods, Journal of Urban Economics, 19, 356-370.

[20] Wildasin D. E, 1988a, Interjurisdictional Capital Mobility: Fiscal Externality and a corrective subsidy, Journal of Urban Economics, 25,193-212.

[21] Wildasin D.E., 1988b, Nash Equilibria in Models of Fiscal Competition, Journal of Public Economics, 35, 229-240.

[22] Wilson J.D., 1995, Mobile Labor, Multiple Tax Instruments, and Tax Competition, Journal of Urban Economics, 38, 333-356. 


\section{Recent titles \\ CORE Discussion Papers}

2008/58. Marie-Louise LEROUX, Pierre PESTIEAU and Gregory PONTHIERE. Should we subsidize longevity?

2008/59. J. Roderick McCRORIE. The role of Skorokhod space in the development of the econometric analysis of time series.

2008/60. Yu. NESTEROV. Barrier subgradient method.

2008/61. Thierry BRECHET, Johan EYCKMANS, François GERARD, Philippe MARBAIX, Henry TULKENS and Jean-Pascal VAN YPERSELE. The impact of the unilateral EU commitment on the stability of international climate agreements.

2008/62. Giorgia OGGIONI and Yves SMEERS. Average power contracts can mitigate carbon leakage.

2008/63. Jean-Sébastien TANCREZ, Philippe CHEVALIER and Pierre SEMAL. A tight bound on the throughput of queueing networks with blocking.

2008/64. Nicolas GILLIS and François GLINEUR. Nonnegative factorization and the maximum edge biclique problem.

2008/65. Geir B. ASHEIM, Claude D'ASPREMONT and Kuntal BANERJEE. Generalized timeinvariant overtaking.

2008/66. Jean-François CAULIER, Ana MAULEON and Vincent VANNETELBOSCH. Contractually stable networks.

2008/67. Jean J. GABSZEWICZ, Filomena GARCIA, Joana PAIS and Joana RESENDE. On Gale and Shapley 'College admissions and stability of marriage'.

2008/68. Axel GAUTIER and Anne YVRANDE-BILLON. Contract renewal as an incentive device. An application to the French urban public transport sector.

2008/69. Yuri YATSENKO and Natali HRITONENKO. Discrete-continuous analysis of optimal equipment replacement.

2008/70. Michel JOURNÉE, Yurii NESTEROV, Peter RICHTÁRIK and Rodolphe SEPULCHRE. Generalized power method for sparse principal component analysis.

2008/71. Toshihiro OKUBO and Pierre M. PICARD. Firms' location under taste and demand heterogeneity.

2008/72. Iwan MEIER and Jeroen V.K. ROMBOUTS. Style rotation and performance persistence of mutual funds.

2008/73. Shin-Huei WANG and Christian M. HAFNER. Estimating autocorrelations in the presence of deterministic trends.

2008/74. Yuri YATSENKO and Natali HRITONENKO. Technological breakthroughs and asset replacement.

2008/75. Julio DÁVILA. The taxation of capital returns in overlapping generations economies without financial assets.

2008/76. Giorgia OGGIONI and Yves SMEERS. Equilibrium models for the carbon leakage problem.

2008/77. Jean-François MERTENS and Anna RUBINCHIK. Intergenerational equity and the discount rate for cost-benefit analysis.

2008/78. Claire DUJARDIN and Florence GOFFETTE-NAGOT. Does public housing occupancy increase unemployment?

2008/79. Sandra PONCET, Walter STEINGRESS and Hylke VANDENBUSSCHE. Financial constraints in China: firm-level evidence.

2008/80. Jean GABSZEWICZ, Salome GVETADZE, Didier LAUSSEL and Patrice PIERETTI. Pubic goods' attractiveness and migrations.

2008/81. Karen CRABBE and Hylke VANDENBUSSCHE. Are your firm's taxes set in Warsaw? Spatial tax competition in Europe.

2008/82. Jean-Sébastien TANCREZ, Benoît ROLAND, Jean-Philippe CORDIER and Fouad RIANE. How stochasticity and emergencies disrupt the surgical schedule.

2008/83. Peter RICHTÁRIK. Approximate level method.

2008/84. Çağatay KAYI and Eve RAMAEKERS. Characterizations of Pareto-efficient, fair, and strategyproof allocation rules in queueing problems. 


\section{Recent titles}

\section{CORE Discussion Papers - continued}

2009/1. Carlo ROSA. Forecasting the direction of policy rate changes: The importance of ECB words.

2009/2. Sébastien LAURENT, Jeroen V.K. ROMBOUTS and Francesco VIOLANTE. Consistent ranking of multivariate volatility models.

2009/3. Dunia LÓPEZ-PINTADO and Juan D. MORENO-TERNERO. The principal's dilemma.

2009/4. Jacek B. KRAWCZYK and Oana-Silvia SEREA. A viability theory approach to a two-stage optimal control problem of technology adoption.

2009/5. Jean-François MERTENS and Anna RUBINCHIK. Regularity and stability of equilibria in an overlapping generations model with exogenous growth.

2009/6. Nicolas GILLIS and François GLINEUR. Using underapproximations for sparse nonnegative matrix factorization.

2009/7. Michel M. DENUIT, Louis EECKHOUDT and Mario MENEGATTI. Correlated risks, bivariate utility and optimal choices.

2009/8. Michel M. DENUIT, Louis EECKHOUDT and Mario MENEGATTI. Adding independent risks in an insurance portfolio: which shape for the insurers' preferences?

2009/9. Antoine BOMMIER and Stéphane ZUBER. The Pareto principle of optimal inequality.

2009/10. Raouf BOUCEKKINE, Jacek B. KRAWCZYK and Thomas VALLEE. Environmental negotiations as dynamic games: Why so selfish?

2009/11. Théophile T. AZOMAHOU, Raouf BOUCEKKINE and Phu NGUYEN-VAN. Promoting clean technologies under imperfect competition.

2009/12. Patrice PIERETTI and Skerdilajda ZANAJ. On tax competition, public goods provision and jurisdictions' size.

\section{Books}

H. TULKENS (ed.) (2006), Public goods, environmental externalities and fiscal competition. New York, Springer-Verlag.

V. GINSBURGH and D. THROSBY (eds.) (2006), Handbook of the economics of art and culture. Amsterdam, Elsevier.

J. GABSZEWICZ (ed.) (2006), La différenciation des produits. Paris, La découverte.

L. BAUWENS, W. POHLMEIER and D. VEREDAS (eds.) (2008), High frequency financial econometrics: recent developments. Heidelberg, Physica-Verlag.

P. VAN HENTENRYCKE and L. WOLSEY (eds.) (2007), Integration of AI and OR techniques in constraint programming for combinatorial optimization problems. Berlin, Springer.

P-P. COMBES, Th. MAYER and J-F. THISSE (eds.) (2008), Economic geography: the integration of regions and nations. Princeton, Princeton University Press.

J. HINDRIKS (ed.) (2008), Au-delà de Copernic: de la confusion au consensus ? Brussels, Academic and Scientific Publishers.

\section{CORE Lecture Series}

C. GOURIÉROUX and A. MONFORT (1995), Simulation Based Econometric Methods.

A. RUBINSTEIN (1996), Lectures on Modeling Bounded Rationality.

J. RENEGAR (1999), A Mathematical View of Interior-Point Methods in Convex Optimization.

B.D. BERNHEIM and M.D. WHINSTON (1999), Anticompetitive Exclusion and Foreclosure Through Vertical Agreements.

D. BIENSTOCK (2001), Potential function methods for approximately solving linear programming problems: theory and practice.

R. AMIR (2002), Supermodularity and complementarity in economics.

R. WEISMANTEL (2006), Lectures on mixed nonlinear programming. 